\title{
New records of Psilidae, Piophilidae, Lauxaniidae, Cremifaniidae and Sphaeroceridae (Diptera) from the Czech Republic and Slovakia
}

\author{
Jindřich Roháček, Miroslav Barták \& Jiř́i Preisler
}

\begin{abstract}
New records of Psilidae, Piophilidae, Lauxaniidae, Cremifaniidae and Sphaeroceridae (Diptera) from the Czech Republic and Slovakia. - Acta Mus. Siles. Sci. Natur. 65: 51-62, 2016.

Abstract: Records of eight rare species of the families Psilidae (4), Piophilidae (1), Lauxaniidae (1), Cremifaniidae (1) and Sphaeroceridae (1) from the Czech Republic, Slovakia and Austria are presented and their importance to the knowledge of the biodiversity of local faunas is discussed along with notes on their biology, distribution and identification. Psilidae: Chamaepsila tenebrica (Shatalkin, 1986) is a new addition to the West Palaearctic fauna (recorded from the Czech Republic and Slovakia); Ch. andreji (Shatalkin, 1991) and Ch. confusa Shatalkin \& Merz, 2010 are recorded from the Czech Republic (both Bohemia and Moravia) and Ch. andreji also from Austria for the first time, and Ch. unilineata (Zetterstedt, 1847) is added to the fauna of Moravia. Also Homoneura lamellata (Becker, 1895) (Lauxaniidae) and Cremifania nigrocellulata Czerny, 1904 (Cremifaniidae) are first recorded from Moravia and Copromyza pseudostercoraria Papp, 1976 (Sphaeroceridae) is a new addition to faunas of both the Czech Republic (Moravia only) and Slovakia, and its record from Moravia represents a new northernmost limit of its distribution. Pseudoseps signata (Fallén, 1820) (Piophilidae), an endangered species in the Czech Republic, is reported from Bohemia for second time. Photographs of Chamaepsila tenebrica (male), Pseudoseps signata (living female), Homoneura lamellata (male), Cremifania lanceolata (male) and Copromyza pseudostercoraria (male) are presented to enable recognition of these species.
\end{abstract}

Key words: Diptera, Psilidae, Piophilidae, Lauxaniidae, Cremifaniidae, Sphaeroceridae, new records, Czech Republic (Bohemia, Moravia), Slovakia, biology, distribution, identification

\section{Introduction}

The contemporary preparation of a new (3rd) electronic version of the Checklist of Diptera of the Czech Republic and Slovakia initiated an effort to publish records of the majority of species discovered in these countries during past six years. This paper is therefore aimed at presenting new records of several such taxa of the acalyptrate families Psilidae, Lauxaniidae, Cremifaniidae and Sphaeroceridae to supplement information about the dipterous fauna of the Czech Republic and Slovakia last summarized in version 2 of checklists of Psilidae by Barták \& Carles-Tolrá (2009), Lauxaniidae by Dvořáková \& Gaimari (2009), Cremifaniidae by Roháček \& Barták (2009) and Sphaeroceridae by Roháček (2009). Besides these, a second record of a rare species of Piophilidae, Pseudoseps signata (Fallén, 1820), from Bohemia is also treated below because it is important from the nature conservancy point of view.

\section{Material and methods}

The material examined is deposited in collections as follows: MBP - collection of Prof. Dr. Miroslav Barták, CSc., Praha; SMLC - Severočeské muzeum, Liberec; SMOC - Silesian Museum, Opava, Czech Republic.

Specimens have been examined using binocular stereoscopic and compound microscopes (Reichert, Olympus, Jenaval, Carl Zeiss, Nikon SMZ-1500). When necessary male genitalia and female terminalia were examined after detachment, treating in hot $10 \% \mathrm{KOH}$, washing in water and dissection of the whole abdomen in a drop of glycerine under a binocular microscope. After examination, all parts were transferred to a small plastic tube in glycerine and pinned below the respective specimens; this is indicated by the abbreviation "genit. prep." in the list of material examined. Some of the collected adults were retained alive in plastic tubes to be 
photographed shortly after being captured in special boxes by means of digital cameras Canon EOS $60 \mathrm{D}$ and Canon EOS 5D Mark II with a macro lens (Canon MP-E $65 \mathrm{~mm} \mathrm{1-5 \times )} \mathrm{and} \mathrm{ring} \mathrm{macro} \mathrm{flash} \mathrm{(Canon} \mathrm{MR-14EX).}$ Dead dried and mounted specimens have been photographed by the same equipment (J. Roháček) or by means of a Canon digital camera mounted on a Nikon SMZ-1500 microscope and images were edited with the computer software NIS-Elements 3.0. Each image resulted usually from combining 15 layers and was improved by means of Adobe Photoshop software (M. Barták).

\section{Results}

\section{PSILIDAE}

\section{Chamaepsila andreji (Shatalkin, 1996)}

Material examined: CZECH REPUBLIC: N Bohemia: Bílina, Chloumek, 50³2'38" N, 1351'32" E, 480 m, hill top steppe, Malaise trap, 28.v.-15.vi.1998, 1q, M. Barták leg., V. Martinek det. 1999 as Psila nigrosetosa (MBP); Březno nr. Chomutov, nr. Hutná brook, 50²4'24" N, 13²3'21" E, 285 m, Malaise trap, 14.v.-27.v.2000,

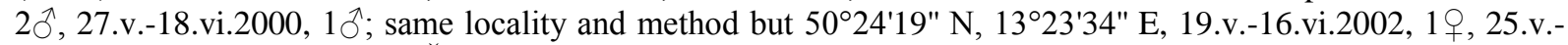
22.vi.2003, 1 ㅇ, M. Barták \& Š. Kubík leg., all V. Martinek det. 2001 as Psila nigrosetosa (MBP); Jizerské hory Mts, Rejdice, Ješkrabec brook, 650 m, Malaise trap, 5.vii.-28.vii.2005, 2へ̂, P. Vonička \& J. Preisler leg. (SMLC); C Bohemia: Praha, Holešovice, 5007' N, 1426' E, 200 m, along river, 14.vi.1988, 19; Praha, Prokopské údolí, 5002' N, 14²3' E, 280 m, steppe, 25.v.1992, 1웅 all M. Barták leg., V. Martinek det. 1993 as Psila nigrosetosa (MBP); Dobřejovice, yellow pan traps, v. 2000, $1 \delta^{\lambda} 1$ q, J. Farkač leg., V. Martinek det. 2003 as Psila nigrosetosa (MBP); S Moravia: Podyjí NP, pod Šobesem, 4848'48" N, 1558'51"E, wetland nr. river,

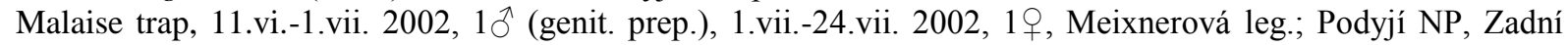

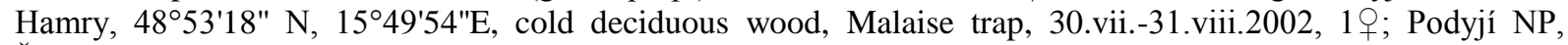

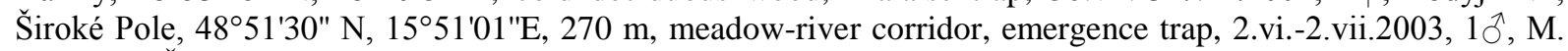
Barták \& Š. Kubík leg., all V. Martinek det. as Psila nigrosetosa (all MBP); N Moravia: Chlebičov (distr. Opava), Svobodský les, sweeping undergrowth of mixed forest, 8.vi.1994, $1 ð 2$ \% ; Chlebičov (distr. Opava), holt nr. dump, sweeping undergrowth of mixed forest, 21.vi.1994, $1 \delta^{\Uparrow} 2$, all J. Roháček leg. (SMOC); NE Moravia: Třrinec, Jahodná, 4946' N, 1843' E, 400 m, 1.viii.1981, 1ㅇ․ M. Barták leg., V. Martinek det. 1982 as Psila nigrosetosa (MBP).

SLOVAKIA: E Slovakia: Slovenský kras, Zádiel, at light, 30.viii.1980, 1ठ̄, J. Roháček leg., V. Martinek det. 1982 as Psila nigrosetosa; Snina env., shore of Cirocha river, sweeping undergrowth of deciduous forest, 2.vi.1984, 1§̂, J. Roháček leg., V. Martinek det. 1986 as Psila nigrosetosa; Malé Trakany, nr. Tisa river, sweeping undergrowth of deciduous forest, 5.vi.1988, 1§̂, J. Roháček leg., V. Martinek det. 1991 as Psila nigrosetosa (all SMOC).

AUSTRIA: Grossglockner N, spruce wood, 400 m, 31.vii.1988, 1§^, M. Barták leg., V. Martinek det. 1990 as Psila nigrosetosa (MBP), all J. Preisler \& J. Roháček det. (or rev.).

Biology: No previous data. The majority of specimens examined have been caught by means of Malaise traps and/or swept from low vegetation in undergrowth of mixed or deciduous forests at low to middle altitudes.

Distribution: The original description of $C h$. andreji was based on a single male from Russia: N Ossetia, Caucasus (Shatalkin 1996). The species has only recently been found in northern Italy (Shatalkin \& Merz 2010) near Verona (A. I. Shatalkin, personal communication 2013) and subsequently reported from Slovakia: Muránska planina Mts (Roháček 2013). Based on records listed above the species is probably widespread in temperate Europe but has been overlooked because formerly determined as Ch. nigrosetosa Frey, 1925 (see below). There are a number of records of Ch. nigrosetosa both from the Czech Republic and Slovakia, and it is probable that some (or most) of them are based on specimens of $C h$. andreji misidentified by V. Martinek as Ch. nigrosetosa. This is true for some Czech records from the Bílina and Duchcov environs (Martinek \& Barták 2001) in N. Bohemia, the Podyjí National Park (Martinek et al. 2005) in S. Moravia as well as for Slovak records from Snina-Cirocha river (Roháček 1995) and Slovenský kras-Zádiel (Roháček 2012) we have revised. First records from the Czech Republic (both Bohemia and Moravia) and Austria. 

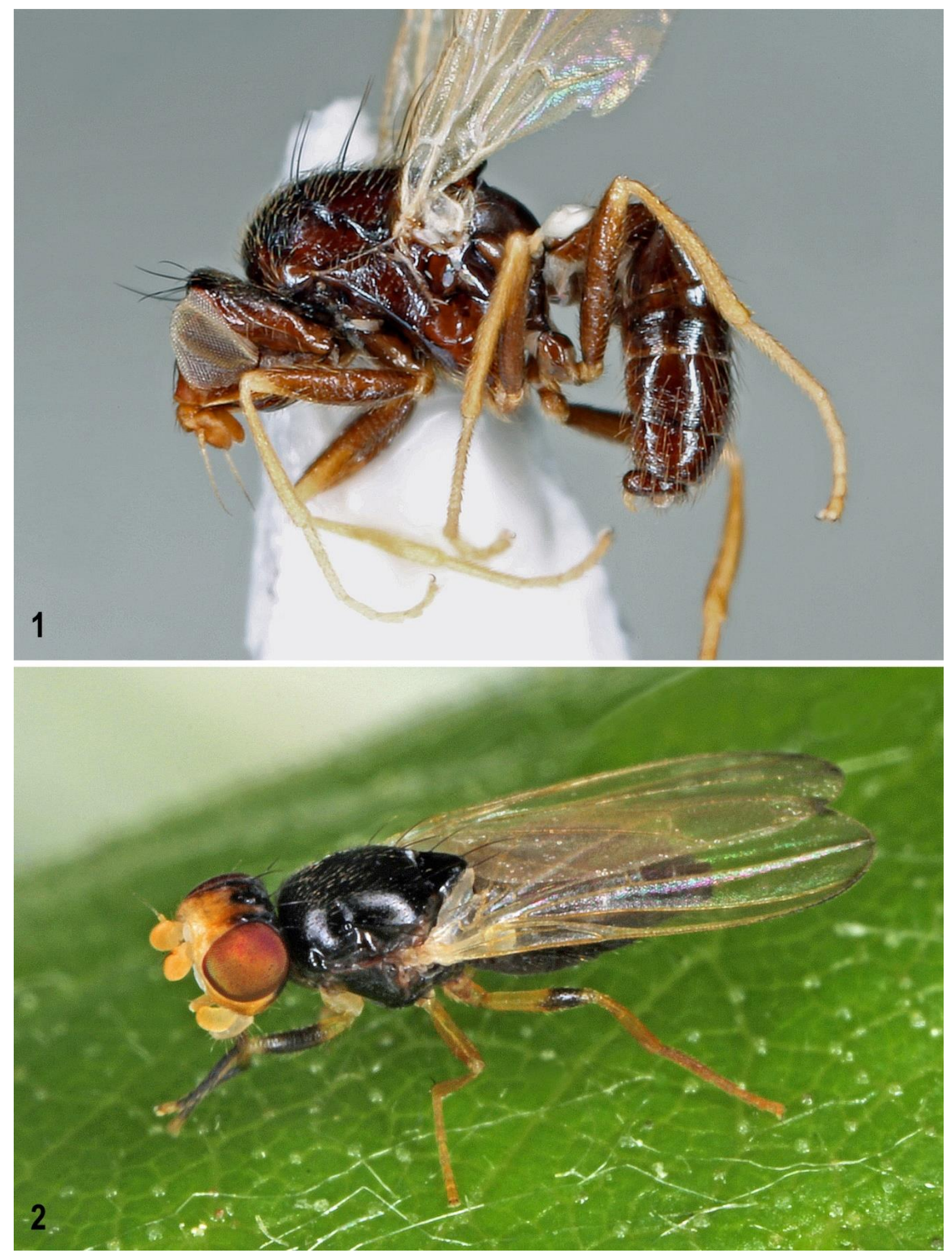

Figs 1-2: Psilidae and Piophilidae: 1 - Chamaepsila tenebrica (Shatalkin), male laterally, body length $2.7 \mathrm{~mm}$ (N Bohemia: Bílina, Štěpánov); 2 - Pseudoseps signata (Fallén), living female dorsolaterally, body length 3.5 mm (N Bohemia: Jesenný-Bohuňovsko). Photo by J. Roháček. 
Comments: Because of cephalic and thoracic chaetotaxy and general colouration Ch. andreji has previously been mixed with $C h$. nigrosetosa. Like the latter species $C h$. andreji has the entire thorax and head orange-yellow (with only ocellar triangle black), abdominal terga black and apex of palpi darkened but differs from it by the black 1st flagellomere, paler (yellow to brown) cephalic and thoracic setae and structures of the male genitalia (see Roháček 2013: Figs 1-2).

\section{Chamaepsila confusa Shatalkin \& Merz, 2010}

Material examined: CZECH REPUBLIC: N Bohemia: Bílina, Holibka, 50³1'19" N, 1349'47"E, 360 m, lowland wood, Malaise trap, 9.viii.-23.ix.1998, 1ð̄, M. Barták leg. (MBP); SW Bohemia: Šumava Mts, Horská Kvilda env., sweeping over meadow, 2.ix.1994, 1ð̊; Šumava Mts, Horská Kvilda-Zhůřské slatě (mire), sweeping over peat-bog meadow, 3.ix.1994, 1ㅇ, both J. Roháček leg. et det. (V. Martinek det. 1996 as Psila persimilis, SMOC); NW Moravia: Moravičany nr. Mohelnice, sweeping over boggy meadow, 24.viii.1980, 10̂, J. Roháček leg. et det. (V. Martinek det. 1988 as Psila persimilis, SMOC); N Moravia: Albertovec env. (distr. Opava), sweeping undergrowth of mixed forest, 22.viii.1989, 19, J. Roháček leg. et det. (SMOC); NE Moravia: Bystřice

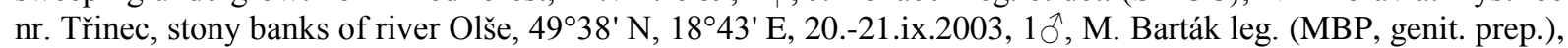
all J. Preisler \& J. Roháček det. (or rev.).

Biology: Poorly known. In the Muránska planina Mts a series of specimens were swept from grassy margin of beech forest or caught in a nearby situated Malaise trap (Roháček 2013). Adults seem to occur in late summer (from end of June to end of September) which is also confirmed by the above records.

Distribution: Inasmuch as this species has been formerly mixed with the similarly coloured Ch. persimilis (Wakerley, 1959) its distribution is incompletely known. Shatalkin \& Merz (2010) described Ch. confusa from France and Switzerland and Roháček (2013) recorded it from Slovakia (Muránska planina Mts). First records from the Czech Republic (both Bohemia and Moravia) are listed above. Because most of the revised specimens were originally identified by V. Martinek as Ch. persimilis it is possible that some previous records of the latter species from the Czech Republic (e.g. Martinek \& Barták 2001) and/or Slovakia refer in fact to Ch. confusa.

Comments: Externally, Ch. confusa closely resembles $C h$. persimilis, including the yellow spot on proepisternum of propleuron but differs from the latter in having apically blackened palpus, entirely black 1st antennal flagellomere (Roháček 2013: Fig. 4) and distinctly different male genitalia (cf. Shatalkin \& Merz 2010: Fig. 1).

\section{Chamaepsila tenebrica (Shatalkin, 1986) (Fig. 1)}

Material examined: CZECH REPUBLIC: N Bohemia: Bílina, Štěpánov, 50³1'59" N, 1351'39" E, 380 m, mixed wood nr.brook, Malaise trap, 13.-28.v.1998, 5ふ̂, 28.v.-15.vi.1998, 3 ふૈ, M. Barták leg., all V. Martinek det. 1979 as Psila nigra (MBP, SMOC, $1 \delta^{\Uparrow}$ genit. prep.); České Středohoří PLA, Bílé Stráně res., 12.v.2005,

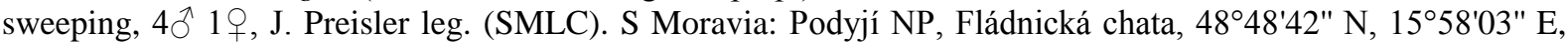
360 m, forest, Malaise trap, 29.iv.-21.v.2004, 1ㅇ, M. Barták \& Š. Kubík leg., V. Martinek det. as Psila nigra (MBP).

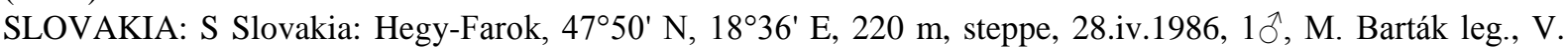
Martinek det. 1988 as Psila nigra (MBP), all J. Preisler \& J. Roháček det.

Biology: Unknown. Specimens from the E. Palaearctic (see below) were collected in June and July (Shatalkin 1986, 2007) and those from South Korea (Shatalkin 2007) were swept from riverbed ruderal vegetation. The material examined originates from warm localities at low altitudes and was captured by Malaise traps or swept from low vegetation both in forested and open (steppe) habitats and adults were collected earlier (end of April to June).

Distribution: The species has hitherto been only known from the East Palaearctic (Shatalkin 2008). It was described from the Russian Far East (Primorski krai, Khabarovski krai) (Shatalkin 1986) and since only recorded from South Korea (Shatalkin 2007). The above new records from the Czech Republic (both Bohemia and Moravia) and Slovakia are the first from 
the West Palaearctic. The species has obviously been mixed under Ch. nigra (Fallén, 1820) (see commens below) and, therefore, it is expected to be found also in other parts of Europe and in the intervening areas of Palaearctic Asia.

Comments: Ch. tenebrica is a dark (blackish brown) species very similar (including chaetotaxy) to Ch. nigra. It differs from the latter in having the head with frons and gena more extensively yellowish to reddish brown, antennae yellowish brown (see Fig. 1) including 1st flagellomere which can be darkened only dorsally and apically (the latter completely black in Ch. nigra), and markedly lighter legs with all tibiae yellow (mid and hind tibiae brown in Ch. nigra). Comparison of structures of the male genitalia of a specimen from Bohemia revealed a surprising similarity to those illustrated by Shatalkin (1986). Because the majority of C. European specimens recorded above were originally misidentified as Ch. nigra by V. Martinek it is probable that also some other records of this common species may include misidentified specimens of $C h$. tenebrica.

\section{Chamaepsila unilineata (Zetterstedt, 1847)}

Material examined: CZECH REPUBLIC: Vráž nr. Písek, Novovrážský rybník (pond), sweeping \& yellow pan traps, 20.-26.vi.2009, 2ᄋ; Vráž nr. Písek, 49²4' N, 147-8' E, 400 m, meadow, aromata, pan traps, 18.-

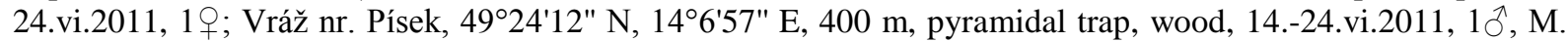
Barták leg. (MBP); N Bohemia: Vítkov nr. Česká Lípa, 5041' N, 14³6' E, sweeping undergrowth of mixed forest, 14.vi.2005, 1ð̂, J. Roháček leg. (SMOC); S Moravia: Dolnodunajovické kopce res. (distr. Břeclav), sweeping over steppe meadow, 15.v.2001, $1 \delta^{\Uparrow} 1$ \% , J. Roháček leg. (SMOC); Bílé Karpaty Mts, Žerotín, Malaise trap, 26.vi. 2008, 1웅 Chvojka, Ježek \& Macek leg. (SMLC).

SLOVAKIA: E Slovakia: Ruský Potok env. (distr. Humenné), sweeping undergrowth of alder forest, 17.vi.1986, 1 ( (V. Martinek det.); Nová Sedlica env. (distr. Humenné), sweeping undergrowth of deciduous forest, 10.vi.1996, 1ठో; Nová Sedlica-Zbojský potok (distr. Humenné), sweeping undergrowth of deciduous forest, 11.vi.1996, 1 q (both V. Martinek det. as Psila nigrosetosa), both J. Roháček leg. (SMOC), all J. Preisler \& J. Roháček det. (or rev.).

Biology: Largely unknown. Adults occur in June and July in Switzerland, from lowland to about $1600 \mathrm{~m}$ (Shatalkin \& Merz 2010). The specimens examined were collected in June, from low vegetation in forested and (less frequently) open habitats.

Distribution: Because this species, particularly its pale variety, has been confused with $C h$. pallida (Fallén, 1820) (see comments below) its distribution is imprecisely known, probably occurring in North and Central Europe. There is only a single record from the Czech Republic (N Bohemia: Zahrádky), see Martinek (1974) and also the records from Slovakia are very scarce: Martinek (1979) reported Ch. unilineata from the Belianske Tatry Mts and Roháček (1995) from the Bukovské vrchy Mts in E Slovakia. The first records from Moravia (Czech Republic) are given above along with additional records from Slovakia and from Bohemia.

Comments: $C h$. unilineata has long time been considered a variety of $C h$. pallida or only the specimens with typically developed dark stripes on the mesonotum were identified as $C h$. unilineata. Shatalkin \& Merz (2010) characterized Ch. unilineata as a species with variable colouration of the mesonotum (with dark stripes often faded to almost invisible) differing from Ch. pallida in having darkened subscutellum, dark abdominal terga and different male genitalia. V. Martinek even misidentified some specimens as Ch. nigrosetosa Frey, 1925 (see material examined) although this species differs markedly from Ch. unilineata in having shortly pilose arista, blackish cephalic and thoracic macrosetae and subscutellum yellow. Note: a male recorded above from Dolnodunajovické kopce res. possesses 3 orbital setae as in Ch. triorbiseta Papp, 2003 and has the subscutellum only a little darkened although otherwise agrees with the pale form of Ch. unilineata. This fact confirms the latter as a highly variable species. 


\section{PIOPHILIDAE}

Pseudoseps signata (Fallén, 1820) (Fig. 2)

Material examined: CZECH REPUBLIC: N Bohemia: Jesenný-Bohuňovsko, Kamenice river, 50³9'33" N, 15²19'33" E, 330 m, sweeping riverside vegetation, 27.v.2014, 1ㅇ․ J. Roháček leg. et det. (SMOC, photographed, Fig. 2).

Biology: Insufficiently known due to general scarceness of the species. All records of $P$. signata from the Czech Republic (see below) and Slovakia (Roháček 2001; Barták \& Roháček 2009) originate from deciduous or mixed forests, usually situated near brooks or rivers. Despite its known distribution (see below) the records from Central Europe are from low to middle altitudes $(240-800 \mathrm{~m})$. The above record agrees well with this information inasmuch as the above specimen was swept from undergrowth of an alder forest on the bank of the Kamenice river.

Distribution: Pseudoseps signata has long been known only from Great Britain and northern Europe (Denmark, Sweden, Finland) (Ozerov 2013); the first records from Central Europe have been published from the Czech Republic (Barták 2001) and Slovakia (Roháček 2001), see also Barták (2009). The only Czech records originate from $\mathrm{N}$ Bohemia (Dubina nr. Duchcov, Štěpánov) (Barták 2001) and S Moravia (Podyjí NP: Havraníky) (Barták \& Kubík 2005). The above finding confirm the occurrence of the species also at the foot of the Jizerské hory Mts where it was formerly unknown (cf. Barták et al. 2009).

Comments: Pseudoseps signata is distinguished by its sexual dichroism of the legs: the male has them completely yellow, while the female has them with blackish brown to brown subapical rings on the fore and hind femora, and its fore tarsus is entirely dark except for the terminal segment (see Fig. 2). Also the brownish clouds at the apices of $R_{2+3}, R_{4+5}$ and $M$ are more distinct in the male than in the female. Due to its rarity this species is treated as endangered (EN) in the Czech Republic (Barták 2005) and, therefore, every additional record is important to be registered.

\section{LAUXANIIDAE}

\section{Homoneura lamellata (Becker, 1895) (Figs 4, 5)}

Material examined: CZECH REPUBLIC: SW Moravia: Jihlava-Pávov, 49²6'26" N, 15³5'44" E, 495 m, wetland nr. pond, Malaise trap, 5.vii.-10.viii.2009, 1§̃, M. Barták leg. et det. (MBP).

Biology: Poorly known; the species has been most frequently collected in June and July, but occuring from May to early August. Remm (1972) reported the species to be rare in damp forests.

Distribution: H. lamellata is the only Palaearctic representative of the Homoneura fraterna group, subgenus Homoneura, which is otherwise distributed in the Nearctic Region (Miller 1976). From the Czech Republic it was first reported by Martinek (1997); a few later records have been added by Martinek (2001) and recently by Dvořák et al. (2010) but all these are from Bohemia. First record from Moravia.

Comments: This species, distinguished by its maculated wings (Fig. 5) and peculiar spinose sternal processes on the male abdomen (Fig. 4), is generally rare in Central Europe, and is considered endangered (EN) in the Czech Republic (Martinek \& Barták 2005).

\section{CREMIFANIIDAE}

\section{Cremifania nigrocellulata Czerny, 1904 (Fig. 3)}

Material examined: CZECH REPUBLIC: NE Moravia: Bystřice nad Olší, 49³8'00" N, 1842'46" E, 335 m, damp wood, MT, 3.v.-6.vi.2009, 1ð̂, M. Barták leg., M. Barták \& J. Roháček det. (MBP). 


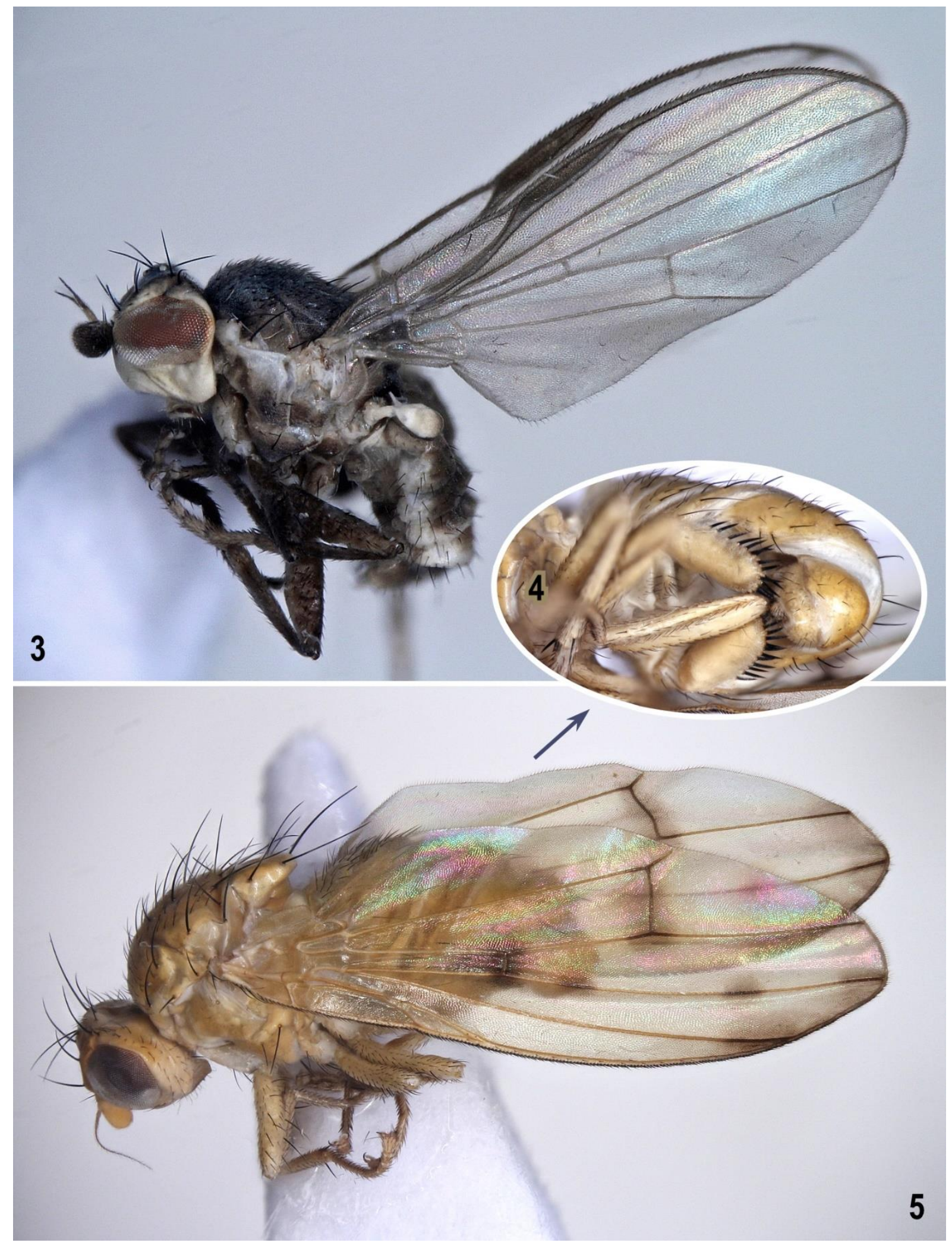

Figs 3-5: Cremifaniidae and Lauxaniidae. 3 - Cremifania lanceolata Czerny, male, body length $1.8 \mathrm{~mm}(\mathrm{NE}$ Moravia: Bystřice nad Olší); 4 - Homoneura lamellata (Becker), male abdomen ventrally; 5 - same specimen, male laterally, body length $3.2 \mathrm{~mm}$ (SW Moravia: Jihlava-Pávov). Photo by M. Barták. 
Biology: This uncommon species is associated with coniferous trees because its larvae are parasitoids of balsam woolly aphids of the family Adelgidae, particularly Dreyfusia piceae (Ratzeburg, 1844). Because of this close affinity adults of $C$. nigrocellulata are rarely encountered in field although the species can sometimes occur in numbers in heavy balsam woolly aphid infestations on pines (Pschorn-Walcher \& Zwölfer 1960) and has even been introduced to North America to control this aphid pest (Delucchi \& Pschorn-Walcher 1954; McAlpine 1963). The male recorded above was collected by means of a Malaise trap in a small (largely deciduous) flooded forest surrounding the Olše river.

Distribution: Apart from introductions to the USA (Oregon) and Canada (New Brunswick, Newfoundland) (McAlpine 1963) the species is only known from Central Europe (Germany, Switzerland, Austria, Czech Republic, Slovakia). In the Czech Republic it was only recorded from the Šumava Mts in SW Bohemia (Roháček \& Barták 2006) and, therefore, the above record is the first from Moravia.

Comments: Currently, four species of Cremifaniidae, all belonging to Cremifania Czerny, 1904, are known worldwide, and three of them in Europe (Papp 2010). The Czech Republic is the only country where 2 species of the genus were encountered, viz. $C$. nigrocellulata and $C$. lanceolata Papp, 1994 (see Roháček \& Barták 2001). The third European species, $C$. bulgarica Papp, 2010, has recently been described from single male found in Bulgaria but its occurrence in warmest areas of Central Europe cannot be also excluded.

\section{SPHAEROCERIDAE}

\section{Copromyza pseudostercoraria Papp, 1976 (Figs 6, 7)}

Material examined: CZECH REPUBLIC: SW Moravia: Jihlava-Pávov, 49²6'26" N, 15³5'44" E, 495 m, wetland nr. pond, Malaise trap, 10.viii.-4.x.2009, 1ð̂, M. Barták leg. (SMOC).

SLOVAKIA: S Slovakia, Mužla env., Jurský Chlm res., 47²4'50" N, 18³2'11" E, 113 m, sweeping vegetation along reed bed, 24.iv.2014, 1§̂, J. Roháček leg. (SMOC, genit. prep.), both J. Roháček det.

Biology: The species is probably microcavernicolous, associated like its closest relatives, $C$. stercoraria (Meigen, 1830) and C. montana Roháček, 1992, with runs and burrows of small mammals, and has saprophagous larvae obviously developing in their excrement and nest debris. In contrast to both its above relatives, $C$. pseudostercoraria is a distinctly thermophilous species (cf. its distribution below). In Central Europe (Hungary - Papp 1976, Switzerland - Papp 1998) it has only been known from lowlands, and, therefore, its occurrence in lowlands of S. Slovakia has long been expected (Roháček 1989, 1992) and is now confirmed by the above record. On the other hand, the new record from uplands at Jihlava (SW Moravia) is rather surprising and may indicate a spreading of the species further north (and higher altitudes) due to warming of climate.

Distribution: $C$. pseudostercoraria is only known from South and Central Europe and the Near East of Asia. Marshall et al. (2011) summarized its records as follows: Spain, France, Italy, Switzerland, Hungary, Greece, Israel and Iran. The above records are the first from Slovakia and the Czech Republic and the latter represents a new northernmost occurrence limit of the species.

Comments: Both specimens are of typical colouration, with all femora largely yellow (see Fig. 6) differing so distinctly from those of $C$. stercoraria and $C$. montana. The male from Jihlava-Pávov has well visible gonostyli (Fig. 7) so that it has been retained intact. The abdomen of the male from Jurský Chlm was detached and genitalia dissected to confirm the identification. Unfortunately, the gonostyli were damaged in the course of dissection, with apices broken off. For identification of all these three species, see the key and illustrations in Roháček (1992). 


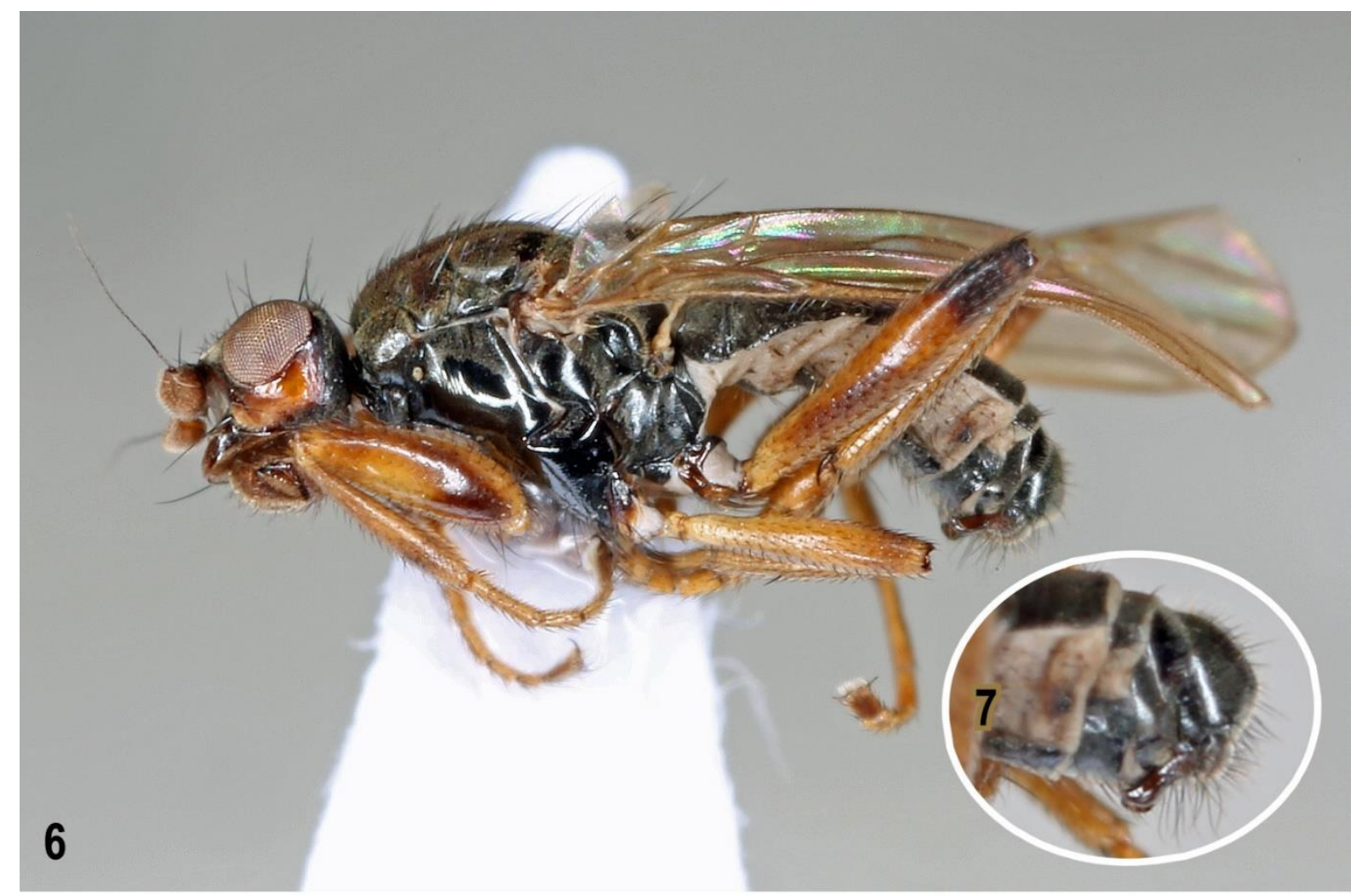

Figs 6-7: Sphaeroceridae. 6 - Copromyza pseudostercoraria Papp, male laterally, body length $3.4 \mathrm{~mm}$ (SW Moravia: Jihlava-Pávov); 7 - same specimen, male postabdomen laterally. Photo by J. Roháček.

\section{Discussion and conclusions}

The faunal novelties to the Czech and Slovak fauna presented above have contributed not only to the better knowledge of the species richness of Diptera in these countries but also to the precision of the hitherto poorly known distribution of these generally rare species. This is particularly true for species of the genus Chamaepsila Hendel, 1917 (Psilidae) recorded here from the Czech Republic and Slovakia, one of which, Ch. tenebrica, has previously been only known from the East Palaearctic area (see Shatalkin 1986, 2007, 2008), and, consequently, is a new addition to the European fauna. Also the finding of Copromyza pseudostercoraria (Sphaeroceridae) in Slovakia and, especially, in Moravia (Czech Republic) is another biogeographically important fact that seems to indicate a spreading of this thermophilous species to more northern latitudes of Central Europe because its former northermost records were from Switzerland (Papp 1998) and southern Hungary (Papp 1976).

Acknowledgements: It is an agreeable duty to express our gratitude to A. I. Shatalkin (Moscow, Russia) for information about Chamaepsila species he described and provision of Russian literature, and to M. Semelbauer (Bratislava, Slovakia) for useful comments on Homoneura lamellata. We would like to thank P. Chandler (Melksham, England) for comments and language corrections and M. Tkoč (Praha, Czech Republic) for review of this paper. The study was partly (J. Roháček) financially supported by the Ministry of Culture of the Czech Republic by institutional financing of long-term conceptual development of the research institution (the Silesian Museum, MK000100595), internal grant of the Silesian Museum No. IGS201607/2016.

\section{References}

Barták M. (2001): Piophilidae. In Barták M. \& Vaňhara J. (eds): Diptera in an industrially affected region (north-western Bohemia, Bílina and Duchcov environs), II. - Folia Fac. Sci. Nat. Univ. Masaryk. Brun., Biologia 105: 283-287. 
- (2005): Piophilidae (sýrohlodkovití). P. 317. In Farkač J., Král D. \& Škorpík M. (eds): Červený seznam ohrožených druhů České republiky. Bezobratlí. Red list of threatened species in the Czech Republic. Invertebrates. Agentura ochrany př́rody a krajiny České republiky, Praha, 760 pp.

- (2009): Piophilidae Macquart, 1835. In Jedlička L., Kúdela M. \& Stloukalová V. (eds): Checklist of Diptera of the Czech Republic and Slovakia. Electronic version 2. http://www.edvis.sk/diptera2009/ families/piophilidae.htm + CD-ROM: ISBN 978-80-969629-4-5.

Barták M. \& Carles-Tolrá M. (2009): Psilidae Loew, 1861. In Jedlička L., Kúdela M. \& Stloukalová V. (eds): Checklist of Diptera of the Czech Republic and Slovakia. Electronic version 2. http://www.edvis.sk/ diptera2009/families/psilidae.htm + CD-ROM: ISBN 978-80-969629-4-5.

Barták M. \& Kubík Š. (2005): Piophilidae. Pp. 251-252. In Barták M. \& Kubík Š. (eds): Diptera of Podyjí National Park and its Environs. Česká zemědělská univerzita v Praze, Praha, 432 pp.

Barták M., Preisler J. \& Vonička P. (2009): Sýrohlodkovití (Diptera: Piophilidae) Jizerských hor a Frýdlantska. Piophilidae (Diptera) of the Jizerskéh hory Mts and Frýdlant region (northern Bohemia, Czech Republic). - Sbor. Severočes. Muz. Př́r. Vědy, Liberec 27: 55-58 (in Czech, English summary).

Barták M. \& Roháček J. (2009): Piophilidae. Pp. 193-195. In Roháček J. \& Ševčík J. (eds): Diptera of the Pol'ana Protected Landscape Area - Biosphere Reserve (Central Slovakia). SNC SR, Administration of the PLA - BR Pol'ana, Zvolen, 340 pp.

Delucchi V. \& Pschorn-Walcher H. (1954): Cremifania nigrocellulata (Diptera, ?Chamaemyiidae), ein Rauber am Dreyfusia (Adelges piceae Ratz., Hemiptera, Adelgidae). - Ztschr. Angew. Entomol. 36: 84-107.

Dvořák L., Sychra L. \& Dvořáková K. (2010): Poznámky k entomofauně bývalé pískovny u Pamferovy Huti (SZ Šumava) [Notes to the entomofauna of former sand-pit near Pamferova Hut' (southwestern Bohemian Forest)] - Erica, Plzeň 17: 103-121 (in Czech, with English abstract).

Dvořáková K. \& Gaimari S.D. (2009): Lauxaniidae Macquart, 1835. In Jedlička L., Kúdela M. \& Stloukalová V. (eds): Checklist of Diptera of the Czech Republic and Slovakia. Electronic version 2. http://www.edvis.sk/diptera2009/families/lauxaniidae.htm + CD-ROM: ISBN 978-80-969629-4-5.

Marshall S.A., Roháček J., Dong H. \& Buck M. (2011): The state of Sphaeroceridae (Diptera: Acalyptratae): a world catalog update covering the years 2000-2010, with new generic synonymy, new combinations, and new distributions. - Acta Entomol. Mus. Natn. Pragae 51(1): 217-298.

McAlpine F. (1963): Relationships of Cremifania Czerny (Diptera, Chamaemyiidae) and description of a new species. - Can. Entomologist 95(3): 239-253.

Martinek V. (1974): Nové nálezy druhů skupiny Acalyptrata (Diptera) v severních a severovýchodních Čechách. More interesting species of the group Acalyptrata (Diptera) from northern and northeastern Bohemia. - Sbor. Severočes. Mus. Ser. Nat. Liberec 6: 151-175 (in Czech, with English summary).

- (1979): Druhy čeledí Psilidae a Megamerinidae (Diptera), zastoupené ve sbírkách Moravského muzea v Brně. Species of families Psilidae and Megamerinidae (Diptera) represented in the collections of the Moravian Museum in Brno. - Acta Mus. Mor., Sci. Nat. 64: 103-113 (in Czech, with English summary).

- (1997): The newest finds of some species of the group Acalyptrata (Diptera) in the territory of the Czech and Slovak Republics. In Vaňhara J. \& Rozkošný R. (eds): Dipterologica Bohemoslovaca, Vol. 8. - Folia Fac. Sci. Nat. Univ. Masaryk. Brun., Biol., 95: 111-114.

- (2001): New or scarce Acalyptrate flies (Diptera) found in the forests of the Czech and Slovak Republics. - J. Forest Sci. 47: 523-528.

Martinek V. \& Barták M. (2001): Psilidae. In Barták M. \& Vaňhara J. (eds): Diptera in an industrially affected region (north-western Bohemia, Bílina and Duchcov environs), II. - Folia Fac. Sci. Nat. Univ. Masaryk. Brun., Biologia 105: 263-268.

- (2005): Lauxaniidae (sýrohlodkovití). P. 321. In Farkač J., Král D. \& Škorpík M. (eds): Červený seznam ohrožených druhů České republiky. Bezobratlí. Red list of threatened species in the Czech Republic. Invertebrates. Agentura ochrany př́rody a krajiny České republiky, Praha, 760 pp.

Martinek V., Barták M. \& Kubík Š. (2005): Psilidae. Pp. 239-242. In Barták M. \& Kubík Š. (eds): Diptera of Podyjí National Park and its Environs. Česká zemědělská univerzita v Praze, Praha, 432 pp.

Miller R. M. (1976): The taxonomy and biology of the Nearctic species of Homoneura (Diptera: Lauxaniidae). Retrospective Theses and Dissertations, Paper 5662, Ames, Iowa, 254 pp.

Ozerov A. L. (2013): Fauna Europaea: Piophilidae. In Beuk P. \& Pape T. (eds): Fauna Europaea: Diptera Brachycera. Fauna Europaea version 2.6, http://www.fauna-eu.org

Papp L. (1976): Some terricolous Sphaerocerids and Drosophilids from Hungary (Diptera: Sphaeroceridae and Drosophilidae). - Folia Entomol. Hung. 29(1): 75-85.

- (1998): 86. Sphaeroceridae. Pp. 291-294. In Merz B., Bächli G., Haenni J.-P. \& Gonseth Y. (eds): Diptera - Checklist. Fauna Helvetica 1, Centre suisse de cartographie de la faune \& Sweizerische Entomologische Gesellschaft, Neuchâtel, 369 pp.

- (2010): A new Cremifania species from Bulgaria (Diptera, Cremifaniidae), with proposal for wing venation terms in higher Diptera. - Annales Historico-Naturales Musei Nationalis Hungarici 102: 193-204. 
Pschorn-Walcher H. \& Zwölfer H. (1960): Further observations on European Dreyfusia (Adelges) populations. - Ztschr. Angew. Entomol. 46: 260-273.

Remm E. (1972): [Fauna of Lauxaniidae (Diptera) of the Soviet Baltic Republics]. - Eesti NSV Tead Akad. Tiom. Biol. 21(2): 117-129. (in Russian).

Roháček J. (1989): Sphaeroceridae (Diptera) of Czechoslovakia. Part 1. Lotophila Lioy and Copromyza Fallén. - Čas. Slez. Muz. Opava (A) 38: 1-16.

- (1992): Sphaeroceridae (Diptera) of Czechoslovakia. Part 3. Alloborborus Duda and Copromyza montana sp. n. - Čas. Slez. Muz. Opava (A) 41: 193-203.

- (1995): Psilidae. Pp. 119-120. In Roháček J., Starý J., Martinovský J. \& Vála M. (eds): Diptera Bukovských vrchov. Diptera of the Bukovské Hills. SAŽP - Správa CHKO a BR Východné Karpaty, Humenné, $232 \mathrm{pp}$.

- (2001): Faunistic records: Piophilidae. In Chvála M. (ed.): Dipterologica bohemoslovaca. Vol. 10. - Acta Univ. Carol., Biol. 45: 191-192.

- (2009): Sphaeroceridae Macquart, 1835. In Jedlička L., Kúdela M. \& Stloukalová V. (eds): Checklist of Diptera of the Czech Republic and Slovakia. Electronic version 2. http://www.edvis.sk/diptera2009/ families/sphaeroceridae.htm + CD-ROM: ISBN 978-80-969629-4-5.

- (2012): The fauna of Pseudopomyzidae, Micropezidae, Megamerinidae and Psilidae (Diptera) in the Gemer area (Central Slovakia). - Čas. Slez. Muz. Opava (A) 61: 131-142.

- (2013): The fauna of Acalyptrate families Micropezidae, Psilidae, Clusiidae, Acartophthalmidae, Anthomyzidae, Aulacigastridae, Periscelididae and Asteiidae (Diptera) in the Gemer area (Central Slovakia): supplement 1. - Čas. Slez. Muz. Opava (A) 62: 125-136.

Roháček J. \& Barták M. (2001): Cremifaniidae. In Barták M. \& Vaňhara J. (eds): Diptera in an industrially affected region (north-western Bohemia, Bílina and Duchcov environs), II. - Folia Fac. Sci. Nat. Univ. Masaryk. Brun., Biologia 105: 313-314.

- (2006): Cremifaniidae. Faunistic records from the Czech and Slovak Republics. In Kinkorová J. (ed.): Dipterologica bohemoslovaca Vol. 13. - Acta Univ. Carol., Biol. 50: 156-157.

- (2009): Cremifaniidae McAlpine, 1963. In Jedlička L., Kúdela M. \& Stloukalová V. (eds): Checklist of Diptera of the Czech Republic and Slovakia. Electronic version 2. http://www.edvis.sk/diptera2009/ families/cremifaniidae.htm + CD-ROM: ISBN 978-80-969629-4-5.

Shatalkin A. I. (1986): Obzor vostochnopalearkticheskikh mukh roda Psila Mg. (Diptera, Psilidae) s opredelitel'noj tablitzej palearkticheskikh vidov. [Review of the east Palaearctic flies of the genus Psila Mg. (Diptera, Psilidae), with the key to Palaearctic species]. - Trudy Zool. Inst. AN SSSR 146: 23-43 (in Russian).

- (1996): Novye vidy mukh roda Psila (Diptera, Psilidae) fauny Rossii [New species of the genus Psila (Diptera, Psilidae) of the fauna of Russia]. - Zool. Zhurn. 75: 880-884 (in Russian).

- (2007): The Psilidae (Diptera) from South Korea, with the key to Old World species of Xenopsila Buck. Russ. Entomol. J. 16(4): 487-490.

- (2008): Vostochnopalearkticheskie i oriental'nye vidy mukh roda Psila Meigen (Psilidae). East Palaearctic and Oriental flies of the genus Psila Meigen (Psilidae). - Sbor. Trudov Zool. Muz. MGU 49: 48-69 (in Russian, with English summary).

Shatalkin A. I. \& Merz B. (2010): The Psilidae (Diptera) from Switzerland, with description of new Central European species. - Rev. Suisse Zool. 117(4): 771-800.

\section{Nové nálezy druhů čeledí Psilidae, Piophilidae, Lauxaniidae, Cremifaniidae a Sphaeroceridae (Diptera) z České republiky a Slovenska.}

V práci jsou představeny nové údaje o výskytu osmi vzácných druhů z čeledí Psilidae (4 druhy), Piophilidae (1), Lauxaniidae (1), Cremifaniidae (1) a Sphaeroceridae (1) v České republice, na Slovensku a v Rakousku a diskutován jejich význam pro poznání diverzity regionálních faun těchto zemí spolu s poznámkami k jejich bionomii, rozš́řrení a determinaci. Psilidae: Chamaepsila tenebrica (Shatalkin, 1986) je novým druhem pro faunu západní části Palearktické oblasti (zaznamenán z České republiky i Slovenska); Ch. andreji (Shatalkin, 1991) a Ch. confusa Shatalkin \& Merz, 2010 jsou poprvé hlášeny z území České republiky (oba z Čech i Moravy) a Ch. andreji také z Rakouska, zatímco druh Ch. unilineata (Zetterstedt, 1847) je novým pro faunu Moravy. Rovněž Homoneura lamellata (Becker, 1895) (Lauxaniidae) a Cremifania nigrocellulata Czerny, 1904 (Cremifaniidae) jsou poprvé uvedeny z Moravy a Copromyza pseudostercoraria Papp, 1976 (Sphaeroceridae) je novým jak pro faunu České republiky (zatím pouze Morava) i Slovenska, přičemž nález na jihozápadní Moravě př̀edstavuje nejsevernější hranici jeho rozšiř̌ní. Pseudoseps signata (Fallén, 1820) (Piophilidae), považovaný (podobně jako Homoneura lamellata) v České republice za ohrožený (EN) druh, je zaznamenán podruhé na území Čech. Jsou prezentovány fotografie druhů Chamaepsila tenebrica (samec), Pseudoseps signata 
(samice, zaživa), Homoneura lamellata (samec), Cremifania lanceolata (samec) a Copromyza pseudostercoraria $(\mathrm{samec}) \mathrm{s}$ cílem umožnit lepší rozeznávání těchto vzácných druhů.

Authors' addresses: Jindřich Roháček, Silesian Museum, Nádražní okruh 31 CZ-746 01 Opava,

Czech Republic, e-mail: rohacek@szm.cz

Miroslav Barták, Department of Zoology and Fisheries, Faculty of Agrobiology, Food and Natural Resources, Czech University of Life Sciences, CZ-165 21 Praha 6-Suchdol, Czech Republic, e-mail: bartak@af.czu.cz

Jiří Preisler, Vlnařská 692, CZ-460 01 Liberec, Czech Republic,

e-mail: preisler.blb@seznam.cz 